\title{
INDUSTRIAL DIVERSIFICATION AND FIRM PERFORMANCE OF MANUFACTURING: DOES EFFICIENCY MATTER?
}

\author{
Rahmat Setiawan \\ rahmatsetiawan@feb.unair.ac.id \\ Riska Agustin \\ Faculty of Economics and Business, Universitas Airlangga \\ Jl. Airlangga 4-6, Kota Surabaya 60286, Indonesia
}

received: 26/9/18; revised: 24/11/18; published: 31/12/18

\begin{abstract}
Industrial diversification is one of the important strategies in developing the firm 's market share which is expected to improve firm's performance. When a firm wants to diversify the industry, it requires knowledge and efficiency of managers in managing the strategy so that it can increase the benefits of the existence of industrial diversification relationship with firm's performance. This study aims to examine the effect of efficiency on the relationship between industrial diversification and firm's performance in manufacturing companies in Indonesia. By using the purposive sampling method and the 2012-2016 study periods, we obtained data from 70 manufacturing companies with a total of 253 observations. We found that industrial diversification had a significant positive effect on firm's performance. Efficiency as a moderating variable shows that efficiency strengthens the positive relationship of industrial diversification on firm performance.
\end{abstract}

\section{Keywords: diversification; efficiency; firm's performance; industrial diversification; financial} economics.

\section{INTRODUCTION}

Corporate diversification performance is one of the most frequently examined topics in the strategic management literature in the world although the empirical results have been contradictory (Park \& Jang, 2013). Diversification is one of the right strategies for companies to improve their performance in the short term and has the potential to help businesses gain access to the skills, resources, assets, or competencies that cannot be done by other companies that do not diversify in competitive markets (Chen $\& \mathrm{Yu}, 2012)$. In other literature, diversification is a strategy for business expansion to market forces, sectors, industries/segments, which is largely due to competition in the business environment (Wang, Ning, \& Chen, 2013;Yang \& Yang, 2017; Gyan, Brahmana, $\&$ Bakri, 2017). Diversification strategy is divided into two types: industrial diversification and global diversification (Jafarinejad, Ngo, \& Escobari, 2018). Industrial diversification refers to involvement in different industries or business segments and global diversification refers to operating in different countries (Jafarinejad et al., 2018). Both types of diversification strategies play an important role in the decision of diversification strategies that will be carried out by the firm. In this study, the authors want to focus on the type of industrial diversification. Industrial diversification has benefits in good external financing because companies with diverse activities will have a stable cash flow.

Several previous studies have examined the relationship of industrial diversification to firm's performance. In a study conducted by (Yang \& Yang, 2017) and (Gyan et al., 2017) shows that industrial diversification has a significant positive relationship to firm's performance. Meanwhile, (Prada, Delgadorodriguez, \& Romero-jord, 2018) in his research found that industrial diversification by companies adds no effect relationship on firm's performance. However, (Santarelli \& Tran, 2016) in his research found that industrial diversification has a curvilinier effect on profitability. When viewed from the results of inconsistent research, the researcher tried to include a moderation variable to determine the impact on the relationship of industrial diversification on the firm's performance. In the previous literature, some researchers have tried to include moderation variables such as ownership structures, economic environmental effects, corporate governance tools, technological effects and efficiency (Gyan et al., 2017).

Researchers will include efficiency moderation variable in this study to determine the impact of these 
variables on the relation of industrial diversification and firm's performance. Efficiency is an important phenomenon in an effort to improve firm's performance because the firm will try to use its resources more precisely (Gyan et al., 2017). Efficiency in the skills, expertise and decisions of managers in implementing managerial tasks is a key factor in the success of diversification (Bettis \& Prahalad., 1995; Gyan et al., 2017). In Indonesia, the use of efficiency moderating variables in the relationship of industrial diversification and firm's performance is also still rarely used.

Thus, there are two main objectives of this study, (1) to examine the effect of industrial diversification on firm's performance, and (2) to know the effect of efficiency as a variable on the relationship of industrial diversification on firm's performance. The ideal measuring of company's efficiency implies comparing its results with others that researchers consider optimal use all the factors affecting each company to achieve their profitability (Pajares, Moral, Jurado, \& Viruel, 2015). In this study, to measure the level of efficiency of the firm is by using the Data Envelopment Analysis (DEA) method. DEA is a self-evaluation method which assesses the relative efficiency of a particular decision making umit (DMU) within a group of DMUs which can be applied in real world scenarios ( $\mathrm{Zhu}, \mathrm{Wu}, \&$ Song, 2017). DEA is used to assess firm efficiency scores which indicate whether a DMU is relatively efficient or inefficient in comparison to the other DMU in the analysis (Fazlollahi \& Franke, 2018)

Firm's performance is the firm's ability to manage the resources that are owned so as to increase the value of the firm. Measurement of firm's performance can be done by measuring performance related to the firm's operating activities. This measurement is a measurement based on the firm's accounting information (Mukhopadhyay \& Chakraborty, 2017). Diversification is one of the strategies to maintain competitiveness and increase the profitability of the firm (Chen \& Yu, 2012). Diversification refers to an increase by a firm of business in which it operates, be that diversity related or unrelated to product, geographical markets or knowledge (Delbufalo, Poggesi, \& Borra, 2016). Firms choose the diversification strategy when they see an opportunity for more robust growth and higher profitability at a time when the market or the economy is uncertain or when it is hard to expect future growth from their present product (Shin, Ahn, \& Lee, 2015). There are three main motives for the firm to choose diversification as its strategy: market power view, resource based view, agency view. Industrial diversification is defined as the firm's activity in developing market share by having more than one type of industry segment (Mukhopadhyay \& Chakraborty, 2017).

Efficiency is an effort made by a firm to be able to use minimal inputs to produce maximum output so as to maximize the value of the firm (Gyan et al.,
2017). The concept of efficiency in a firm's business is defined as trying to do something in the right way to achieve its goals by not wasting time, effort, or cost. Changes in efficiency reflect the firm's current and future profitability and provide information power to the firm to increase the forecasting about profitability in the future (Baik, Chae, Choi, \& Farber, 2012).

Based on the theory that has been explained, this study will discuss the relationship between industrial diversification and firm's performance in moderation by efficiency. Industrial diversification carried out by the firm by developing more than one industry segment aims to improve firm's performance. The performance improvement was due to the utilization of the firm's internal resources and increased strength in the face of competitors. The main benefit of industrial diversification is from internal capital market (Prada et al., 2018). Utilizing internal resources to different business segments can precisely reduce transaction and tax costs incurred by the firm. Reducing transaction costs that are offset by increased product demand from different segments can increase the firm's profitability. So:

H1: Industrial diversification has a positive effect on firm performance.

The firm's goal in improving performance can be achieved by creating the right strategy, gathering the resources needed and using these resources to achieve firm's goals. Companies that did industrial diversification are trying to allocate their resources effectively to different business segments through efficiency carried out by firm management. According to (Gyan et al., 2017) efficiency is an effort made by a firm to be able to use minimal inputs to produce maximum output so as to maximize the value of the firm. Allocating the firm's internal resources to different industry segments efficiently is expected to increase the benefits of industrial diversification in terms of reducing transaction costs and expanding the firm's network. In this study, efficiency is used as a moderation variable because of the efficiency in the relationship of industrial diversification and the firm's performance can reduce the operational costs and time needed by the firm so as to produce higher profitability. Based on the explanation above, the following hypothesis can be formulated:

$\mathrm{H}$ 2: The positive relationship of industrial diversification on performance is stronger in an efficient companies compared to inefficient companies.

\section{METHODS}

In this study the methodology that is used was adopted from the research of (Gyan et al., 2017), but some measurement proxies used had differences. The data in this study are derived from the annual financial statements of manufacturing companies 
listed on the Indonesia Stock Exchange (IDX) in the period of 2012-2016 which are sourced from www.idx. co.id or by downloading financial reports from their respective websites. Companies with incomplete data and not fulfilling the criteria in the Data Envelopment Analysis (DEA) program in the 2012-2016 periods will be excluded from the sample. This Study is a quantitative study on manufacturing companies listed on the Indonesia Stock Exchange (IDX).

In determining the firm's performance, the measurement used is to use Return on Assets (ROA). The traditional accounting-based performance indicator (ROA) reflect a firm;s short-term profits (Lin \& Chang, 2015). Industrial diversification measurements will be calculated using the Herfindhal index, adopted from research (Farooqi, Harris, \& Ngo, 2014). The determination of efficiency was carried out by using Data Envelopment Analysis (DEA) method to classify efficient and inefficient companies. Following the research conducted by (Doaei \& Shavazipour, 2013) and (Gyan et al., 2017) the variables used as output and input to measure the efficiency of variables that have a significant effects on firm's performance. Output variables used in this study are Return on Equity (ROE), Net Profit Margin (NPM) and Market to Book Ratio (MBR), while the input variables used are firm size, leverage, and capital investment. In this study, the control variables used are firm size and firm age. Table 1 below contains definitions of the variables used in the study.

According to (Coelli, 1998) the concept defines efficiency as the ratio between output and input taking into account more than one input. The more output that is produced from one input unit will result in a higher level of efficiency. If the level of output produced from one input unit has reached the maximum amount that can be produced, then it can be said to have achieved absolute efficiency or optimal efficiency. The approach used in measuring the level of efficiency of manufacturing companies in this study is a non-parametric approach using the Data Envelopment Analysis (DEA) method. Data Envelopment Analysis (DEA) is a mathematical technique with the application of a linear program that measures the relative efficiency of each production unit compared to other production units in managing resources so that they become output (Coelli, 1998).

DEA is a technique that fundamentally measures the efficiency which allows identifying the best performance in the use of resources and this approach was generalized to situations of multiple inputs and outputs (Charles \& Cornillier, 2017). The purpose of DEA is minimizes input and maximizes outputs (Cook, Tone, \& Zhu, 2014). The production unit in the DEA is called a Decision Making Unit (DMU) or the unit being tested which can be in the form of a firm or an institution that wants to be evaluated. Mathematical equations for calculating the efficiency of the DMU or unit tested are as follows (Gyan et al., 2017):

$$
\max _{v, u} \theta=\frac{\sum_{r=1}^{s} u_{1} y_{1 j}+u_{2} y_{2 j}+\cdots u_{s} y_{s j}}{\sum_{i=1}^{m} v_{1} x_{1 j}+v_{2} x_{2 j}+\cdots v_{m} x_{m j}}
$$

With:

$$
\begin{gathered}
\frac{\sum_{r=1}^{s} u_{r} y_{r j}}{\sum_{i=1}^{m} v_{i} x_{i j}} \leq 1, j=1, \ldots, n \ldots \ldots \\
u_{1}, u_{2}, \ldots, u_{s} \geq 0 \\
v_{1}, v_{2}, \ldots, v_{m} \geq 0
\end{gathered}
$$

Where,

$\mathrm{j}=$ DMU that was observed,

$\mathrm{s}=$ output of DMU $\mathrm{j}$ that was observed

$\mathrm{m}=$ input DMU $\mathrm{j}$ that was observed

$\mathrm{u}=$ the weight of the DMU output that was observed

$y=$ the number of DMU outputs that are observed

$\mathrm{v}=$ weight of DMU input $\mathrm{j}$ that was observed

$\mathrm{x}=$ the number of DMU inputs that are observed.

In equation (1), $\mathrm{n}$ is the number of DMU in the sample and $\mathrm{j}$ is the type of DMU that was sampled in the study. The first equation explains that the ratio for other DMUs is not more than 1 . The second and third equation explain that weights must be positive. The efficiency score generated in this method is between 0 - 1 . In the results issued by the DEA, if a DMU has a value less than 1 then it is considered as an inefficient unit compared to other units.

The effect of industrial diversification on firm's performance with age and firm size control variables, it is necessary to build a regression equation model as follows:

$$
\begin{aligned}
& \text { ROA }_{i, t}=\alpha+\beta_{1} \operatorname{INDUSTRI}_{i, t}+\beta_{2} \text { Age }_{i, t}+\beta_{3} \text { Size }_{i, t}
\end{aligned}
$$

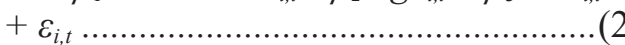

The effect of industrial diversification on firm performance is moderated by efficiency variables and with control variables are age and firm size, it is necessary to build a regression equation model as follows:

$$
\begin{aligned}
\text { ROA }_{i, t}= & \alpha+\beta_{1} \text { INDUSTRI }_{i, t}+\beta_{2} \text { EFI }_{i, t}+\beta_{3} \text { INDUSTRI }^{*} \text { EFI }_{i, t} \\
& +\beta_{4} \text { Age }_{i, t}+\beta_{5} \text { Size }_{i, t}+\varepsilon_{i, t} \cdots \cdots \cdots \cdots \cdots \cdots \cdots \cdots \cdots \cdots . .(3)
\end{aligned}
$$

Adopting research from (Gyan, et.al., 2017), the methodology used to determine the relationship between industrial diversification and efficiency-driven firm's performance consists of two stages of analysis. The first phase of the analysis technique of this research aims to measure the efficiency level of manufacturing companies by using Data Envelopment Analysis (DEA) method using DEAP 21 software with predetermined input and output variables. The second phase of this research analysis technique aims to determine the effect 
of industrial diversification on firm's performance and the impact of efficiency moderation variables on the relation of industrial diversification and firm's performance and using control age, and firm size variables using multiple linear regression analysis using SPSS software.

\section{RESULT}

By using 70 data of manufacturing companies in Indonesia, there were 253 observations. The sample data will be analyzed using two technical steps, first Data Envelopment Analysis (DEA) and second, multiple linear regressions. Table 2 below is a descriptive statistical result of each variable used in this study.

According to Table 2, the average value of the ROA variable in this study is 0.08222349 which indicates that the average sample firm generates $8.22 \%$ profit after interest and taxes compared to its total assets. The lowest value of ROA in this study was 0,000180 and the highest value of ROA in this study was 0.421351 . Industrial diversification or symbolized by INDUSTRI shows the level of business concentration carried out by the firm. Based on table 2, the average value of the industrial diversification variable in this study was 0.19208181 . The lowest value for the INDUSTRI variable in this study is 0 which shows that the sample firm does not do industrial diversification. The highest value of the INDUSTRI variable in this study was 0.686478 .

The control variables, firm age (AGE) which is properly proxied between the years of the study and the year of the firm, in table 2 has an average value in this study was 39,00000000. In Table 2, the minimum AGE variable value is 5 , this means that the firm that has the youngest firms in this study is PT. Star Petrochem Tbk (STAR) with the age of 5 years in 2013. The maximum variable value of AGE is 99, this means that the firm oldest in this study is PT. HM SampoernaTbk (HMSP) with the age of 99 years in 2012. The size of the firm or symbolized by SIZE shows the size of the firm profile which is seen from the number of assets it owns. In Table 2 , the average value of the SIZE variable is 14,45807204, this means that the average firm size variable in this study sample is 14,45807204 . The minimum value of the SIZE variable is 11,495728 , which means that the lowest variable value in the sample of this study is 11,495728 and the maximum variable value of SIZE is 18,335466 .

The moderation variable, which is efficiency, shows how efficient the sample firm is in the use of inputs to obtain output in accordance with the calculation of the DEA program. In table 2, the mean value of the efficiency variable is 0.19367589 , this means that the average value of efficiency in this sample is 0.19367589 . The lowest value of efficiency is 0 , which means that the sample companies in this study are inefficient, while the highest value of efficiency is 1 , which means that the sample companies in this study have been efficient.
According to Table 3, independent variables is industrial diversification (INDUSTRI) has a positive relationship with variable firm performance (ROA). For the control variables are firm age (AGE) and firm size (SIZE) has a positive relationship with firm performance (ROA). Moderating variables are efficiency and the relationship between independent variables and moderation has a positive relationship with firm performance (ROA). Correlation between independent variables, control variables and moderation variables with ROA has significant effect on ROA.

\section{DISCUSSION}

In Table 4 model 1, it shows that the industry diversification symbolized by INDUSTRI has a significant positive effect on firm performance (ROA). The significance value of the industry diversification variable is $0.000<0.05$, it can be concluded that the research hypothesis is proven ( $\mathrm{H} 0$ is rejected and $\mathrm{H} 1$ is accepted). This means that the more a firm carries out an industrial diversification strategy, the higher the performance of the firm. A positive relation of diversification and performance is caused by being able to reduce cost increases over time, such as coordination costs, government costs associated with complex structures and cultural differences as well as costs related to operational administration such as legal and finance services can be deployed in several related industries (Chen \& Yu, 2012).

The decrease in transaction costs of a firm has the potential to increase the allocation to the firm's internal capital market. Appropriately allocating internal resources to different industry segments carried out by managers can reduce the transaction and tax costs incurred by the firm. Reducing the cost of this firm can create benefits related to greater market power and excessive utilization of production factors by allocating these resources more efficiently through the firm's internal capital market (Prada et al., 2018) Greater market power will prevent competitors from monopolizing the market and narrowing the space for new competitors. Companies that have greater market power have the potential to help businesses to gain access to greater capabilities, resources, assets or competencies (Chen \& Yu, 2012). This is because companies with many different industry segments will have ease in coordination and transactions internally called internal market mechanisms which are expected to improve firm's performance.

In Table 4 model 2, the results of the interaction between industrial diversification variables and the efficiency symbolized by INDEFI are significantly positive, meaning that efficiency strengthens the positive relationship of industrial diversification on firm's performance. The significance value of the INDEFI variable is 0,000 , which means $<0.05$ so that it can be concluded that the research hypothesis is proven 
(H0 is rejected and $\mathrm{H} 2$ is accepted). This means that the efficiency of the firm will strengthen the positive relationship of industrial diversification on firm's performance.

Industrial diversification by the firm can be modified by an organizational mechanism that can improve firm's performance. The organizational mechanism can be achieved by increasing internal market efficiency in allocating resources to different business segments and maximizing the use of these resources in accordance with the conditions required by the firm (Symeou \& Kretschmer, 2012). The allocation of resources to different business segments requires knowledge in the strategic approach to be carried out. Diversification can be driven by a range of perceived benefit associated with greater market power, more efficient allocation of resourches through internal capital markets, utilization of existing resource in new setteing (Boz, Yigit, \& Anil, 2013). The knowledge and expertise of managers and the views in implementing managerial tasks as efficiently as possible are part of the key factors in the success of industrial diversification (Bettis \& Prahalad, 1995). Companies that did industrial diversification strive to be able to allocate their resources to various different business segments effectively through efficiency carried out by firm management. The more efficient a firm is in managing its resources, the greater the market power of the firm so that it can encourage an increase in firm's performance.

\section{CONCLUSIONS}

The purpose of this study was to examine the effect of industrial diversification on firm's performance and to determine the effect of efficiency variables on the relation of industrial diversification to firm's performance. After two stages of analysis, by using Data Envelopment Analysis (DEA) method to determine the efficiency value of a firm and then using multiple linear regression method to determine the effect between variables, the results of the research are that industrial diversification has a significant positive effect on firm performance. In other words, the higher the level of industrial diversification carried out by the firm, the higher the performance of the firm. Efficiency as a moderating variable shows the results that efficiency strengthens the positive relationship of industrial diversification on firm's performance. The more efficient the firm that did industrial diversification, the higher the performance of said firm.

The contribution that can be given by this research is; first, this research adopts and contributes to agency theory to prove the interaction of efficiency in the relation of industrial diversification and firm's performance. Second, this study provides a view on the new industrial diversification literature because it incorporates efficiency variable in industrial diversification decisions that will be carried out by companies so that companies can find out the limitations in diversifying industries that can improve firm's performance.

\section{REFERENCES}

Baik, B.O.K., Chae, J., Choi, S., Farber, D.B., 2012. Changes in Operational Efficiency and Firm Performance : A Frontier Analysis Approach *. Contemp. Account. Res. XX, 1-32.

Bettis, R.A., K., P.C., 1995. bettis1995.pdf. Strateg. Manag. J. 16, 5-14.

Boz, I.T., Yigit, I., Anil, I., 2013. The Relationship Between Diversification Strategy And Organizational Performance : A Research Intented For Comparing Belgium And Turkey. Procedia - Soc. Behav. Sci. 99, 997-1006.

Charles, V., Cornillier, F., 2017. PT US CR. Expert Syst. Appl.

Chen, C., Yu, C.J., 2012. Managerial ownership , diversification, and firm performance : Evidence from an emerging market. Int. Bus. Rev. 21, 518-534.

Coelli, T., 1998. A multi-stage methodology for the solution of orientated DEA models. Oper. Res. Lett. 23, 143-149.

Cook, W.D., Tone, K., Zhu, J., 2014. Data envelopment analysis : Prior to choosing a model. Omega 44, 1-4.

Delbufalo, E., Poggesi, S., Borra, Si., 2016. Diversification , family involvement and firm performance Empirical evidence from Italian. J. Manag. Dev. 35, 663-680.

Farooqi, J., Harris, O., Ngo, T., 2014. Ac ce p te d cr t. J. Multinatl. Financ. Manag.

Fazlollahi, A., Franke, U., 2018. SC. Int. J. Prod. Econ.

Garrido-prada, P., Delgado-rodriguez, M.J., Romero-jord, D., 2018. Effect of product and geographic diversi fi cation on company performance : Evidence during an economic crisis $\mathrm{n}$ b. Eur. Manag. J. xxx, 1-18.

Gyan, A.K., Brahmana, R., Bakri, A.K., 2017. Research in International Business and Finance Diversi fi cation strategy, e ffi ciency, and fi rm performance : Insight from emerging market. Res. Int. Bus. Financ. 42, 1103-1114.

Jafarinejad, M., Ngo, T., Escobari, D., 2018. Disentangling the impacts of industrial and global diversification on firm risk. Glob. Financ. J.

Lin, C., Chang, C., 2015. Technological Forecasting \& Social Change The effect of technological diversi fi cation on organizational performance : An empirical study of S \& P 500 manufacturing fi rms. Technol. Forecast. Soc. Chang. 90, 575-586.

Meysam, D., Shavazipour, B., 2013. Corporate diversification' $s$ effects on Efficiency and productivity: case study of Manufacturing firms listed in Bursa Malaysia. Int. J. Bus. Dev. Stud. 5, 77-96.

Moral-pajares, E., Mozas-moral, A., Bernal-jurado, E., Medina-viruel, M.J., 2015. Ef fi ciency and exports : Evidence from Southern European companies. J. 
Bus. Res. 68, 1506-1511.

Mukhopadhyay, J., Chakraborty, I., 2017. Research in International Business and Finance Foreign institutional investment, business groups and firm performance : Evidence from India. Res. Int. Bus. Financ. 39, 454-465.

Park, K., Jang, S. (Shawn), 2013. International Journal of Hospitality Management Effects of within-industry diversification and related diversification strategies on firm performance. Int. J. Hosp. Manag. 34, 51-60.

Santarelli, E., Tran, H.T., 2016. Diversification strategies and firm performance in Vietnam Evidence from parametric and semi-parametric. Econ. Transit. 24, 31-68.

Shin, J., Ahn, J., Lee, D., 2015. Technological Forecasting $\&$ Social Change The impact of diversi fi cation with and without commodity bundling on corporate

Table 1. Definition of Variables and Measurements

\begin{tabular}{|c|c|c|}
\hline & Variable & Definition \\
\hline $\begin{array}{l}\text { Firm's } \\
\text { Performance }\end{array}$ & $\begin{array}{l}\text { Return on } \\
\text { Asset (ROA) }\end{array}$ & Net income to total assets \\
\hline Diversification & $\begin{array}{l}\text { In d u s t ri a } 1 \\
\text { (Herfindhal) }\end{array}$ & $\begin{array}{l}1-(\text { segment sale of the firm/total } \\
\text { sales })^{2}\end{array}$ \\
\hline \multirow[t]{2}{*}{ Control } & Firm Size & Natural logarithm of total assets \\
\hline & Age & $\begin{array}{l}\text { Years of running to the research } \\
\text { period }\end{array}$ \\
\hline \multirow[t]{7}{*}{ Efficiency } & Return on & Net income to total equity \\
\hline & Equity (ROE) & \\
\hline & $\begin{array}{l}\text { Net Profit } \\
\text { Margin }(\mathrm{NPM})\end{array}$ & Net income to total sales \\
\hline & $\begin{array}{l}\text { Market to Book } \\
\text { Ratio (MBR) }\end{array}$ & $\begin{array}{l}\text { Market value per share to book value } \\
\text { per share }\end{array}$ \\
\hline & Firm Size & Logarithm natural of total asset \\
\hline & Leverage & Total liabilities to total asset \\
\hline & $\begin{array}{l}\mathrm{C} \text { a } \mathrm{p} \text { i t a } 1 \\
\text { Investment }\end{array}$ & Capital expenditure to total asset \\
\hline
\end{tabular}

Table 3. Correlation Matrix

\begin{tabular}{|c|c|c|c|c|c|c|}
\hline & ROA & $\begin{array}{l}\text { INDU- } \\
\text { STRI }\end{array}$ & AGE & SIZE & $\begin{array}{c}\text { EFISI- } \\
\text { ENSI }\end{array}$ & INDEFI \\
\hline ROA & 1 & & & & & \\
\hline INDUSTRI & $0,255^{*}$ & 1 & & & & \\
\hline AGE & $0,407^{*}$ & 0,099 & 1 & & & \\
\hline SIZE & $0,278^{*}$ & $0,133^{*}$ & $0,317^{*}$ & 1 & & \\
\hline EFISIENSI & $0,334^{*}$ & $-0,014$ & $0,131^{*}$ & $-0,214 *$ & 1 & \\
\hline INDEFI & $0,443 *$ & $0,294 *$ & $0,125^{*}$ & $-0,054$ & $0,635^{*}$ & 1 \\
\hline
\end{tabular}

*Significance of $5 \%$ performance : An empirical analysis in Korea telecommunication markets. Technol. Forecast. Soc. Chang.

Symeou, P., Kretschmer, T., 2012. Diversification and firm performance in dynamic environments : the role of the firm ? s dynamic capabilities and absorptive capacity . Diversification and firm performance in dynamic environments : the. DRUID Soc. 0-26.

Wang, Y., Ning, L., Chen, J., 2013. Product diversification through licensing : Empirical evidence from Chinese firms. Eur. Manag. J. 1-10.

Yang, Y., Yang, L.-T.G., 2017. Product diversification and property performance in the urban lodging market : The relationship and its moderators. Tour. Manag. 59, 363-375.

Zhu, Q., Wu, J., Song, M., 2017. PT US CR. Comput. Oper. Res.

Table 2. Statistical Descriptive of Each Variable

\begin{tabular}{lccccc}
\hline & N & Minimum & Maximum & Mean & Std. Deviation \\
\hline ROA & 253 & 0,000180 & 0,421351 & 0,08222349 & 0,075992535 \\
INDU- & 253 & 0,000000 & 0,686478 & 0,19208181 & 0,228079653 \\
STRI & & & & & \\
AGE & 253 & 5,000000 & 99,000000 & 39,00000000 & 14,709893011 \\
SIZE & 253 & 11,495728 & 18,335466 & 14,45807204 & 1,556710562 \\
EFISI- & 253 & 0,000000 & 1,000000 & 0,19367589 & 0,395961164 \\
ENSI & & & & & \\
$\begin{array}{l}\text { Valid N } \\
\text { (listwise) }\end{array}$ & & & & \\
\hline $\begin{array}{l}\text { Source : Output SPSS } \\
\text { Soun }\end{array}$ & & & &
\end{tabular}

Table 4. Analytical Results of Multiple Linear Regression

\begin{tabular}{lcc}
\hline \multicolumn{1}{c}{ Variabel } & Model 1 & Model 2 \\
\hline Constant & $-0,100^{*}$ & $-0,155^{* *}$ \\
& $(0,012)$ & $(0,000)$ \\
INDUSTRI & $0,067^{* *}$ & $0,0340^{*}$ \\
& $(0,000)$ & $(0,030)$ \\
AGE & $0,002^{* *}$ & $0,001^{* *}$ \\
& $(0,000)$ & $(0,000)$ \\
SIZE & $0,007^{*}$ & $0,011^{* *}$ \\
& $(0,016)$ & $(0,000)$ \\
EFISIENSI & & $0,034^{*}$ \\
& & $(0,012)$ \\
INDEFI & & $0,181^{* *}$ \\
& & $(0,000)$ \\
R-Square & & 0,383 \\
\hline
\end{tabular}

*Significance of $5 \%$

**Significance of $1 \%$ 